\title{
DEVELOPMENT OF OPTIMAL INVENTORY MANAGEMENT MODELS WITH HYBRID PUSH/ PULL SYSTEM AS INCREASED PERFORMANCE OF FISHERY ENTITIES IN NORTH SULAWESI
}

\author{
Anita Ludia Vivian Wauran*), Joseph Nugraha Tangon, Alpindos Toweula \\ Accounting Department, Manado State Polytechnic \\ *Email : anitaludia@gmail.com
}

\begin{abstract}
Proper production and inventory policies are key factors for the success of modern companies in a competitive environment. In order to be a winner and a very high demand, it is very important for the company to overcome the problems of production, timely delivery, and the transfer of which is a limitation or difficult company. There is a need for an optimal management that can manage the resource constraints of a company through the theory constrains of a hybrid policy that collaborates between push strategies, which is to make an order by pull strategy, which is to make it stored (David Claudio, Jie Zhang, and Ying Zhang, 2007). The purpose of this research is to produce an optimal management model with hybrid push/pull system as a manifestion of fishery performance in North Sulawesi.The types of data used in this study are qualitative data and quantitative data, qualitative data directly from primary sources of fisheries entities in North Sulawesi through interviews. While quantitative data is obtained from secondary sources is data of corporate financial statements including production reports of Fisheries Entities in North Sulawesi through documents with all the contents of all fisheries entities.
\end{abstract}

Keywords: Model Development, Management, Push Hybrid System / Fisheries Entity Pull System

\section{INTRODUCTION}

Nowadays there are so many questions for decision makers in the business world both the micro scale and large companies how to determine the production system whether to use push or pull system in its inventory management. This is all due to the limitations of possessed by the business world in this case the company, both limitations external as well as internal limitations of the company, which is makes the limits of the company in achieving its goals. Therefore, efficient and effective use of resources will determine whether the company can survive or compete with other companies. Currently to be able to compete in the business environment one of the necessary is the optimal inventory management in production planning and supervision. 
Over the past 15 years, three important approaches to material requirement planning (MRP), kanban (JIT), and optimized production technology (OPD) have been widely applied in the planning and monitoring of production processes so quickly. Each new system changes the old assumptions and ways of doing things. Methods change not only in the processing process but also the production management. Decision-makers need to decide which approach to adopt that meets current and future needs. So it can determine what systems to choose and use. "The three approaches can be distinguished as the push system (MRP), pull system (JIT) and hybrid push / pull system (TOC).

In order to be a winner and get a high demand order, it is very important for the company to overcome the problem of production costs, timely delivery, and flexibility. It takes a mixed policy (hybrid policy) that combines push strategy, make-to-order with pull strategy, make-to-order. In this policy, the pull strategy is done for routine demand, while customers who inform their needs first or previously treated with push strategy are given high priority than those who do not share information.

One of North Sulawesi's with highly potential in marine resources is the fishing industry. This fishery industry covers fishing business to fishery product processing by national private company involving foreign capital and managed by Micro Small Medium Enterprises (UMKM). From the observations made the constraints faced in the management of these efforts is in terms of optimal inventory management. Business actors have difficulties in determining suitable models for their inventory management in their production systems. Therefore, an optimal inventory management development model is needed through a hybrid push pull system by looking at the limited resources possessed by the entity.

\section{LITERATURE REVIEW}

\subsection{Inventory}

Hansen and Mowen (2003:968) assert that the notion of inventory is "inventory is all the money the organization spends in turning materials throughput", so it can be said that inventory is money invested in everything that aims to sell and extend the notion of traditionally. Inventory can also be defined as a collection of stored materials and resources that are used to meet current and future needs, as Heizer and Render (2004:574) says "Inventory is stored resource that is used to satisfy a current or future need ". Heizer \& Reinder (2004:574) asserts that inventory is an expensive asset for many companies, and can account for $40 \%$ of total capital investment, so entities should recognize that the importance of good inventory control. Inventory control is a very important managerial function, since the company's physical inventory involves the largest investment in the bulk of current assets, to control inventory according to Sofyan Assauri (1990:1985), the purpose are: 1. Keep the company not out of stock so that it can stop the production activities 2. Keeping the inventory determination by the company is not too large or 
excessive and then the cost being not too large 3. Keeping a small purchase can be avoided because it will cause the cost of ordering to be large. It is therefore appropriate that inventory control and control and inventory systems should be considered and managed in an appropriate inventory management system for the entity.

\subsection{Decisions in Management}

The objectives or targets, policies and management decisions of inventory shall be in accordance with the objectives or objectives of the company as a whole, and shall be in accordance with the objectives or targets of the marketing, finance and productivity fields, as shown in Figure 2.1. below this. From the figure it can be seen that inventory decisions are highly dependent on marketing, production and financial decisions.

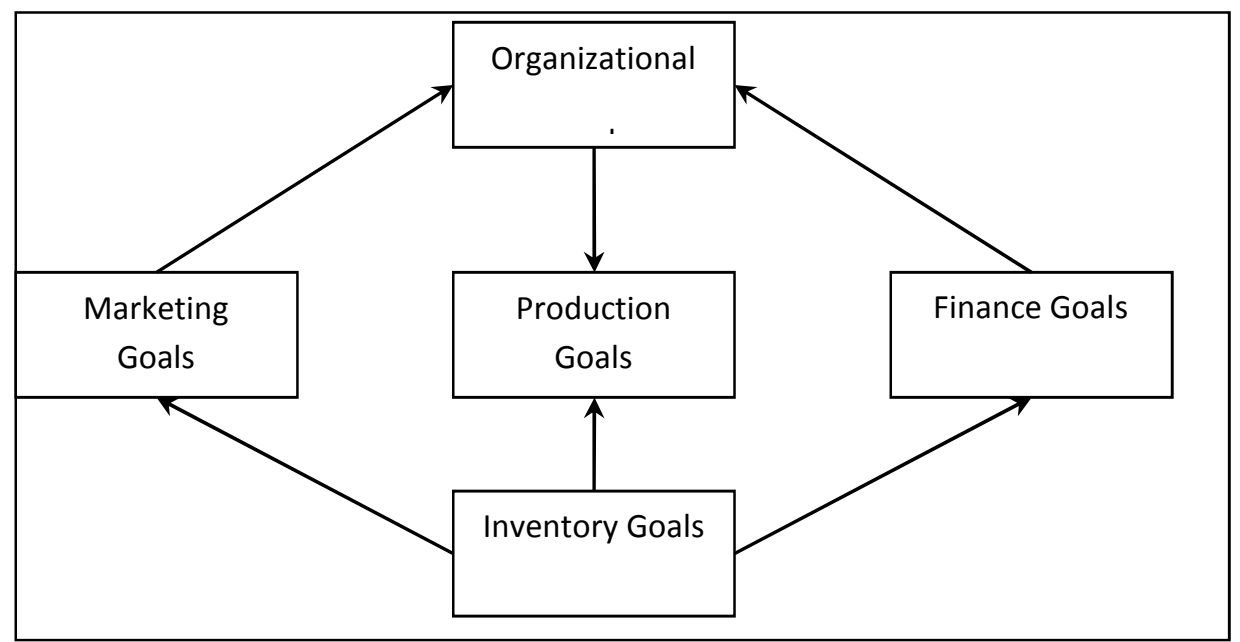

Picture 1. : Relationship of functional Goals

source: Fogarty, Blackstone, Hoffmanhy Production \& Inventory Management,second edition (Cincirmati-south Western Publishing Co), p 15

\subsection{Push system Inventory Control - Material Requirement Planning (MRPI)}

According to the APICS Dictionary (199214o) the push system is: "Theproduction of items at times required by agrives plarmed inadvance Where in the push system the company produces goods at a time determined by a pre-planned schedule In inventory control, inventory expenditures based on predetermined schedule and / or based on initial order Push inventory control system in the process used in Material Requirement Planning (MRP I) Material Requirement Planning I (MRP I) is a formal system that responds to market needs. The system will allow the submission of inventory increases in the process regardless of the current inventory level, which will force the company to first build places for inventory in a process where production capacity is inadequate to handle demand MRP is a system designed in intestines 
for bumpy demand situations, typically because the demand is dependent.

\subsection{Hybrid push/pull system inventory control methods - Theory of Constraints}

The success of the JIT strategy as a pull system and MRP as a push system in inventory control, resulted in the greatest desire to conduct a research of control strategy in manufactured systems, Suri and Krishnamurthy (2003). Basically, inventory planning and control systems can be classified as push, pull or pull / pull system (Karmarkar: 1986). Push system 'linked to Material Requirements Plarnning (MRP) and pull system is also called JIT /kanban system. Currently, the techniques of HT have been described and popularized under the name "Lean Manufacturing" (Womack et al., 1990; Womack and Jones, 1996) that use pull systems as a key component of their strategy. Theory of Constraint (T OC), as a complementary option and methods of previous methods in inventory control systems, each firm faces limited resources and limited demand for each product. Theory of Constraint recognizes that the performance of each firm is limited by its constraints. Then the TOC of control then develops a specific approach to managing constraints to support the goal of continuous improvement, according to TOC, if you want to improve performance, a company must identify its constraints, exploit the constraints in the short run, and in the long run, find ways to overcome them (Hansen Mowen 2003: 490). So for that reason Theory of Constraint (TOC) is used as a hybrid push / pull system inventory control method, which is supposed to be a complement to manage the limitations of the push system (MRPI), then pull system (JIT) as a method that sees the limitations the company hereinafter referred to as constraints, because TOC has a fi lofo fi that is continual improvement that directs the production process to change towards the better, it reflects that the company is required to carry out continuous improvement, besides the TOC also focus on cashfl ow optimization by minimizing the level of supply will cause the cost.

\subsection{Steps in the implementation of hybrid push / pull system - Theory of Contraint}

According to Dugdale and Jones (1995: 134) and Ruhl (1997: 6o-63) TOC is a framework of intuition for the management of an organization. The main purpose behind the TOC is the desire for improved performance on a continuous basis. Goldratts (1990: 1099109) mentions the five steps of Constraints Management as follows: 1 . Identi fi cation of the constraints the system has The constraints or constraints of the enterprise can be divided into two: external limits and internal limits. External boundaries are factors that limit firms from outside sources of the firm (eg demand in the market), whereas internal constraints are limiting factors found inside the company (eg the machine's working time capability). 2. Determine how to exploit the constraints of the system One way to make the best use of binding constraints is to achieve the optimal level of product mix. This step is the main philosophy of Theory Of Constrains (TOC) in the short term. The main Binding Constrains are de fi ned as drummers. So if there is only one limit in the company, then the limit will be de fi ned as a drummer. Theory of Constrains (TOC) is often called the drum-buffer-rope system. 3. Coordinate all according to the decision made in the second step The limitations of the 
drummer process will change the capacity of the entire plant. All departments should be coordinated for the needs of the baselineandrummer. This principle asks many companies to change their views on many things such as the use of the efficiency measures for the departmental level may no longer be necessary, since it encourages the efficiency of the department's production before the drummer process will produce the excess of inventory in the process which, of course, makes the inefficiency in cost. 4. Lifted the boundaries of the system The next step is to start a program of continuous improvement by reducing the limiting limits of the company's performance. 5 . Repeat from the first step This is done if the drummer process above is not become suatubinding constraints anymore. When a drummer batch is detected the above process will be repeated from the first step. The purpose of this is to improve performance in a sustainable manner by managing the existing constraints. The fifth focus of these steps is a simple framework to direct the effort of the thinking process. Using this concept, constraints are seen as restricting the organization to its goals.

\subsection{Disadvantages in the implementation of hybrid push / pull system - Theory of Constraints}

There are any shortcomings in the implementation of Theory of Constrains (TOC). Menumt Taylor (1999: 4) TOC has the following deficiencies: 1 . TOC states that there is no need for applications of overhead and production costs 2. Due to the overcapacity of all unlimited work centers, the efficiency and use of equipment will be moved to all locations with the exception of location and constraints. If management determines to measure production with and coercion and high efficiency and usage levels at all locations, they will be disappointed.

\section{RESEARCH METHOD}

\subsection{Types and Data Sources}

This study uses Primary data in the form of data obtained directly in the field when conducting field research. Secondary data obtained from data sources obtained from existing documents such as financial reports, production reports, inventory reports used by the Fisheries Entity in North Sulawesi plus data from the Central Bureau of Statistics along with data from the Department of Fisheries and Marine Affairs in North Sulawesi. The secondary data used in this study are the 2015 and 2016 annual reports and other information relating to inventory activities in particular the methods in the inventory system. In addition, further research data are obtained from a variety of sources, including: prior articles, books, and research related to optimal inventory management with respect to improving entity performance.

Author uses the data in this study is GDP and consumption Indonesia country, from the year 1967-2014.

\subsection{Data Collection Method}

Data collection in this research is done by several methods, among others are as follows: library research, field research

\subsection{Analysis Method}

This research is descriptive qualitative with the aim to provide an 
initial description of inventory management used by entities ranging from push system, pull system to hybrid push pull system in improving financial performance. To answer the problem formulation, the analytical method used is descriptive qualitative analysis method. With qualitative descriptive analysis method, the data obtained are analyzed qualitatively, that is by reviewing, explaining, analyzing, and explaining the data obtained on the production activity until the production reporting in inventory management. By generating in the first year an optimal model of inventory management development followed in the second year is expected to apply the model to existing fisheries entity in North Sulawesi.

\section{RESULTS AND DISCUSSION}

\subsection{Analysis of Production Cost and Inventory System using Push System and Pull System (Just in Time)}

The current inventory system is a push-system inventory system where production processes are continuously or driven to production based on production schedules or market demands of entities appropriate to the entity's production capacity. Where with the production system implemented at this time with the use of machines as a tool process production electricity costs take the biggest cost in the cost of production today. With this system, the costs incurred in relation to inventory is the cost to obtain raw materials, inventory storage costs in the form of repair and maintenance costs and storage of goods and the cost of depreciation. Costs directly related to the production process, especially the cost of electricity as the engine driving power. So if using this cost will be a lot of costs that will arise in connection with the buildup or storage of inventory.

On the application of the Just in time method inventory will be drawn according to the amount requested now instead of being driven through the system on a fixed jadawal based on consumer anticipation. The JIT system presents a continuous search of the best productivity by clasping waste and inventory regarded as waste. With JIT method is no longer needed inventory burden such as storage of excess inventory, so the cost of depreciation and maintenance is not or becomes nil.

\subsection{Production Cost Analysis of Inventory System by using hybrid method Push / Pull System Sytem Inventory control Method}

In the use and application of the Hybrid Push / Pull system where constraint restrictions are something that limits a company to achieve the objective of feeding the entity or company is capable of using steps to direct its business process :

Identify limits restrictions owned by the company / entity itself

In this case the company must be able to determine the boundaries within the company itself / internal limits as well as the limits of the outside of the company itself / external boundaries; Corporate limitations or inner limitations such as the limitations of raw materials to be used for production as demand increases from consumers, to determine that any resource constraints can be used, companies must seek the optimal level of product mix that will maximize all resources to all firm boundaries. The decision on the product mix will have a huge impact on the profits of the company. Internal Limitations will use the calculation of contribution margin of each product to determine which product will be in maximum production in accordance with its 
external sales level, if the company uses one type of raw material to produce some finished product.

\section{Management of Entity-boundaries}

In order to prevent the loss of sales due to demand in a way, it is desirable that the company / entity produces the reserves / buffers or creates inventory of the reserve chart every month or every production period, while still paying attention to the contribution margin of each product.

\section{Coordinate all production processes based on the first step}

Maximum production will result in excess goods in the production process so that the production part of course must produce as needed in accordance with the demand from the marketing department, which will certainly coordinate with the supervision of the product so as not to experience errors or defects that will affect the production process, especially in using the machine as the main engineer of the production process, which will also affect the increase in electricity consumption, and coupled with production reserves to meet the excess demand.

\section{Increase Limitations of the system}

The next step is to start a program of continuous improvement by reducing the limiting limit of company performance in this case increasing the average limit of units sold by the entity.

\section{Repeat the first step}

This is done if the constraints owned by the company / entity can be overcome then the process will be repeated again from the first step, where the goal of this is to improve performance in a sustainable with the existing restriction management.

With the use of this inventory system is no longer required the storage of finished goods that have not sold, but of course with less amount compared to when using push system method that the cost of production costs, especially costs associated with inventory will be higher than the pull system method but lower than the push system method.

\section{Selection of Inventory Methods with Company Policy}

To be able to realize the mission of the company / entity in obtaining a large profit by being able to meet the needs or demand of goods or products by customers of the company while maintaining the quality and timeliness in meeting the needs of customer needs, the company must be able and observant to read the conditions and business situations in manage or run the company's wheels. One way to be able to achieve these goals should be able to choose a fast and precise inventory method. In the process of choosing the inventory method, it is expected that the company uses measurement based on income and expense from the financial statements to obtain correct and accurate information.

\section{CONCLUSION}

Inventory management using hybrid push / pull system method can optimize the performance of the company's inventory management compared to inventory system conducted by the company so far. Inventory management using hybrid push / pull system is more optimal than the method applied by the 
company / fishery entity currently in improving company performance. Management supplies by using hybrid push / pull system and theory of constraint will be able to optimize the company's financial performance by increasing throughput, minimizing inventory, and lowering the operation so that net income will increase the investment rate will increase as well as cash flow will get better. The hybrid push / pull system method is a process of inventory management that is capable of continuously or sustainably able to

\section{REFERENCES}

APICS Dictionary, (1992), $\quad 7^{\text {th }} e d$. American Production and Inventory Control Society, Falls Church, VA

David, C., Jie Z., dan Ying Z. (2007), A hybrid Inventory Control System Approach Applied To The Food Inventory, The Harold and Inge Marcus Departement of Industrial and Manufacturing Engineering Pennsylvania State University Park, PA 16802, Processings of the 2007 Winter Simulation Conference USA

Gasper, Vincent. (2001). Production Planning and Inventory Control berdasarkan sistem terintegrasi MRP II dan JIT menuju Manufacturing 2. Edisi Revisi. Jakarta Gramedia Pustaka Umum

Hansen, Don R.and Mowen, Maryanne M. (2005). Management Accounting, seventh edition. (Ohio : South-Western), p 811-817

Marcellius, Erics., (2004), Metode Persediaan Hybrid Push/Pull System sebagai sebuah Keunggulan evaluate within the limits of the company in reaching an optimum level called Binding Constrains or drummer, where in the drummer there are buffers and ropes that are able to guarantee inventory the goods in the process do not exceed the level required for time reserves and are able to limit the amount of input ingredients and control effectively the rate at which initial production goes.

Bersaing. Tesis Manajemen Universitas Airlangga Surabaya

Rangkuti, F. (1995), Manajemen Persediaan, Edisi I, PT. Raja grafindo Persada, Jakarta, hlm 10 13

Ruhl, J.M.(1997), Managing Contraints, The CPA Journal, Vol 67 No 1, January,pp 60 -63

Sofyan, A. 1990. Manajemen Produksi LPFE UI, Jakarta, hlm 1 